\title{
Antibodies to skeletal muscle actin and their reactivity with malignant melanoma of the choroid
}

\author{
AMIN MALATY, AMJAD RAHI, AND ALEC GARNER \\ From the Department of Pathology, Institute of Ophthalmology, University of London
}

SUMMARY Imprints of choroidal malignant melanoma cells were treated with serum containing antibodies to a purified preparation of actin derived from skeletal muscle. Evidence of a positive reaction, as shown by indirect immunofluorescence, substantiated an impression based on morphological criteria that choroidal melanoma cells contain actin protein. The significance of this protein in tumour biology is discussed, and a possible interference by antiactin antibodies in the immunodiagnosis of choroidal melanoma is highlighted.

Actin is a globular contractile protein with a molecular weight of about 48000 . Together with myosin it plays a fundamental role in muscular contraction.

Skeletal muscle fibres are composed of a macromolecular complex of polymerised actin and myosin organised into interdigitating filaments which are able to slide over one another. The interdigitations are responsible for the characteristic banded pattern of skeletal muscle fibres. Smooth muscle fibres similarly contain actin and myosin, which may, however, be present either in filamentous ( $F$ actin) or soluble globular forms ( $G$ actin). Furthermore the filaments do not have the banded spatial arrangement of striated muscle but can lie either parallel or at right angles to each other.

Recent studies ${ }^{1-4}$ show that actin, although principally found in muscle fibres, is present in almost all eukaryotic cells, where it can be demonstrated in at least 2 forms: as bundles of filaments or as a randomly orientated meshwork of filaments. ${ }^{5}$ Apart from providing structural support (cytoskeleton), the contractile proteins take part in other mechanicochemical activities of the cell such as cell movement and mitotic division.

The presence of actin in cells which normally display only limited mobility suggests that it performs functions additional to those required in cell movement, such as endocytosis, exocytosis, cell division, and in-vitro attachment to glass surfaces in tissue culture. ${ }^{4-8}$

The content and molecular organisation of actin

Correspondence to Dr A. Malaty, Department of Pathology, Institute of Ophthalmology, Judd Street, London WC1H 9QS. varies in different types of cells as well as being modified by the physiological state of the cell. ${ }^{9-11}$

It has been shown that actin is present in large amounts in malignant tumours arising from some epithelial tissues, ${ }^{9}$ thus implying a possible role in the invasive properties of a malignant tumour. Whether this is true of cancers in general and of malignant melanoma of the choroid in particular is not known. A striking feature of actin in nonmuscle cells is that it aggregates into filaments which can change their pattern and appearance in a matter of hours. ${ }^{11}$ Although some of these changes have been noted in pathological tissues, ${ }^{9}$ they have not been studied in detail, and their significance is largely obscure.

Antibodies reacting with smooth muscle antigens were first described in patients with chronic active hepatitis. ${ }^{12}$ The smooth muscle antibodies (SMA) in such sera were subsequently shown to react with nonmuscle tissues, including the endothelial cells of renal glomeruli, ${ }^{13}$ hepatocytes, ${ }^{12} 1415$ thyroid cells, ${ }^{16} 17$ fibroblasts, ${ }^{18}{ }^{19}$ and platelets. ${ }^{20}{ }^{21}$ All these cell types are now known to contain microfilaments which morphologically resemble the actin filaments seen in muscle tissue. Similar antibodies are now known to occur in the sera of patients with other inflammatory conditions such as cytomegalovirus infection, ${ }^{22}$ mycoplasma pneumonial infection, ${ }^{23}$ infectious mononucleosis, ${ }^{24}$ acute and chronic hepatitis, ${ }^{2526}$ and uveitis. ${ }^{27}$ They are also a feature of a variety of neoplastic states which include basal and squamous cell carcinomas, ${ }^{9}$ Burkitt's lymphoma, nasopharyngeal carcinoma, ${ }^{28}{ }^{29}$ carcinoma of the breast,,$^{30}$ and malignant melanoma of the skin. ${ }^{931}$

In a previous communication, using an indirect 
immunofluorescence test, we showed that sera from patients with a variety of inflammatory eye diseases may similarly contain smooth muscle antibodies. ${ }^{27}$ These sera produced equally strong cytoplasmic fluorescence when tested against choroidal melanoma cell impressions, ${ }^{32}$ which led us to examine the tumour cells for the presence of contractile proteins.

In an ultrastructural study we showed the presence of varying numbers of microfilaments in the cytoplasm of cells from a single malignant choroidal melanoma, but more recently we have demonstrated them in 21 of 22 similar tumours. These microfilaments, ranging in diameter between 5 and $7 \mathrm{~nm}$, were arranged in loose bundles and aligned essentially parallel to the surfaces of the cells, and were consistent morphologically with actin..$^{32}$

In the present communication we describe the reactivity of melanoma cells with antibodies specifically raised against pure actin. This study proves for the first time that choroidal melanoma cells contain actin protein comparable to that found in contractile organs.

\section{Methods and materials}

Actin was extracted from the skeletal muscle of an albino rabbit. Initially a crude extract was obtained by a method essentially similar to that described by Iyengar and Weber. ${ }^{33}$ Finely minced muscle tissue was soaked in $50 \%$ glycerol containing $0.1 \mathrm{M} \mathrm{KC1}$ and $1 \mathrm{mM} \mathrm{MgCl}$ at ph 7 for 3 days. The suspension was filtered and squeezed to remove all the soluble components. The residue was then soaked in a solution containing $0.6 \mathrm{M} \mathrm{KCl}$ and $1 \mathrm{mM}$ adenosine triphosphate in distilled water at $\mathrm{pH} 6.4$ for 24 hours. The insoluble residue obtained after filtration was then treated for 2 successive periods of 30 minutes each in $0.3 \mathrm{M} \mathrm{KC1}$ at $\mathrm{pH} 7$ and $0 \cdot 1 \mathrm{M} \mathrm{KC1}$ at $\mathrm{pH} 9$ respectively. Finally the residue was treated 4 times with distilled water at $\mathrm{pH} 9$. The final residue was dehydrated in acetone and dried overnight. All procedures were carried out in the cold room at a temperature of $4^{\circ} \mathrm{C}$.

\section{PURIFICATION OF ACTIN}

The dried powder thus obtained contained actin which was further purified using the aggregationdisaggregation principle. ${ }^{34}$

Actin was extracted from the acetone-dried powder by suspending it in ice-cooled Tris buffer (2 $\mathrm{mM}$ Tris $\mathrm{HCl}$ (hydroxymethyl methylamine hydrochloride) $0.2 \mathrm{mM}$ ATP, $0.5 \mathrm{mM}$ mercaptoethanol and $0.2 \mathrm{mM} \mathrm{CaCl}_{2}$ at $\mathrm{pH} 8$ ) for 30 minutes. The solution was passed through a coarse sintered glass funnel, and the filtrate was further cleared by

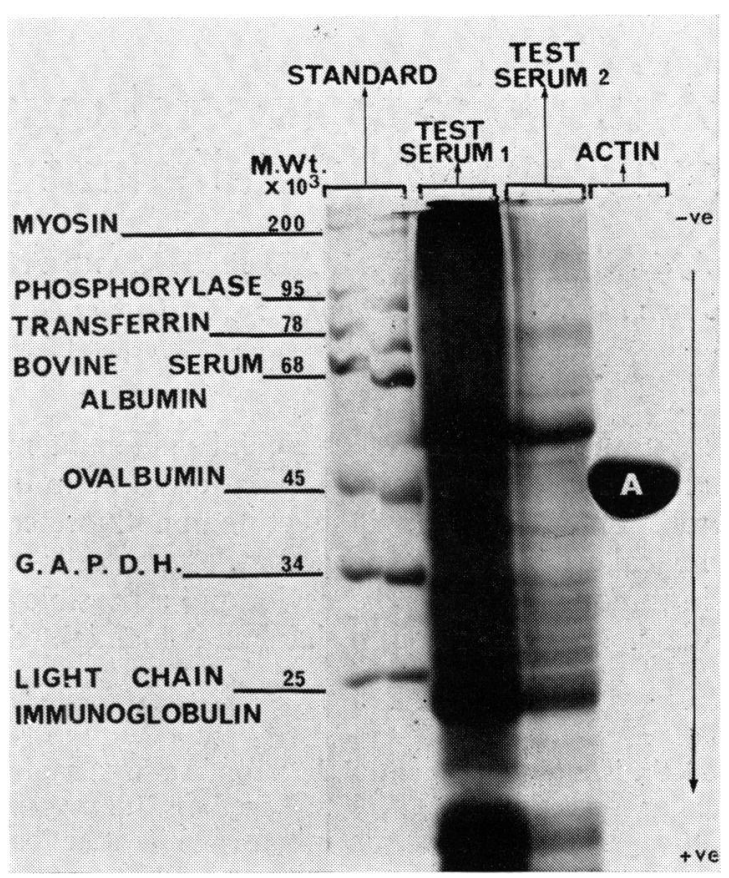

Fig. 1 SDS polyacrylamide gel electrophoresis of the purified actin protein preparation. To provide a scale against which to assess the molecular weight of the test preparation, protein standards of known composition were run in parallel. The resultant mobility of the muscle extract indicated a single component (A) with a molecular weight of approximately 40000-48 000, which compares with the reported size of 48000 for pure actin. (Sera from 2 patients run at the same time are irrelevant to the present study and should be ignored.) $G A P D H=$ glyceraldehyde-3-phosphate dehydrogenase.

centrifugation at $10000 \mathrm{~g}$ for 1 hour. To this supernate $\mathrm{KCl}$ and $\mathrm{MgCl}_{2}$ were added to give a final concentration of $50 \mathrm{mM} \mathrm{KC1}$ and $2 \mathrm{mM}$ $\mathrm{MgCl}_{2}$. The solution was kept on ice for 2 hours in order to polymerise the actin ( $\mathrm{F}$ actin). More $\mathrm{KC} 1$ was then added to the solution to bring its concentration to $0.6 \mathrm{M}$ and left for 90 minutes. The solution was centrifuged for 3 hours at 80000 $g$, and the resulting actin protein pellet was resuspended in buffer and dialysed with vigorous stirring for 3 days at $4^{\circ} \mathrm{C}$, changing to fresh buffer every 24 hours.

The protein concentration in the final solution was measured using a modification of the Lowry technique..$^{35}$

Identification of actin and the assessment of its purity was carried out by sodium dodecyl sulphate polyacrylamide gel electrophoresis. ${ }^{3637}$ Pure actin protein (obtained by the courtesy of Dr M. Owen, 


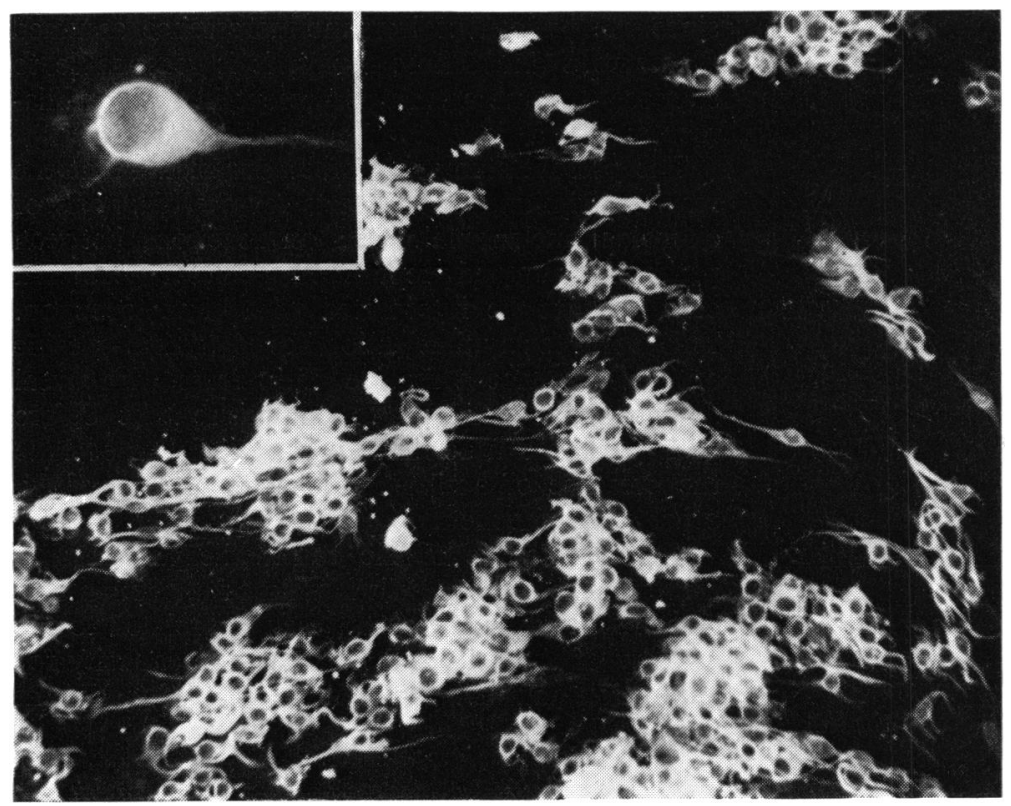

Fig. 2 Indirect immuno-

fluorescence staining of choroidal malignant melanoma cell imprints treated with antiactin antibodies. The bright cytoplasmic fluorescence is indicative of the presence of actin protein $(\times 135$; inset $\times 450)$.

National Institute for Medical Research, Mill Hill, London) and other standard proteins of known molecular weight were used as markers. The protein bands in the gel were fixed overnight in $50 \%$ trichloroacetic acid and then stained with $0.1 \%$ Coomassie brilliant blue solution.

Actin solution was allowed to 'age' by storing for one week at $4^{\circ} \mathrm{C}$, to increase its antigenicity, ${ }^{3}$ and then lyophilised for storage at $-20^{\circ} \mathrm{C}$.

PREPARATION OF ANTISERUM

Albino rabbits were used to raise antiactin antibodies. Before immunisation the serum of each animal was tested for the presence of antibodies to smooth muscle and other autoantibodies by the conventional immunofluorescence test, ${ }^{3}$ and only the animals whose sera gave negative results were used.

Each animal received $1 \mathrm{mg}$ of 'aged' actin redissolved in $\mathbf{0 . 2 5} \mathrm{ml}$ of distilled water and emulsified with an equal volume of Freund's complete adjuvant (Difco Laboratories). The dose was divided between intramuscular and intraperitoneal injections. The animals were bled after 3 weeks and a booster injection was given. Three weeks later the animals were bled again.

STANDARDISATION PROCEDURE

The antisera thus raised were tested for the presence of antiactin antibodies by a standard indirect immunofluorescence test using frozen sections of a composite block consisting of portions of liver, kidney, skeletal muscle, stomach and salivary gland from a rat. Fluorescein labelled antirabbit immunoglobulin was obtained from Nordic Diagnostic and the sections were examined under a Zeiss epifluorescence microscope equipped with an FITC interference filter.

Control studies were carried out by using sera obtained from animals prior to immunisation as well as antiactin sera absorbed with purified actin.

REACTIVITY WITH CHOROIDAL

MALIGNANT MELANOMA CELLS

Eyes with choroidal malignant melanomas were opened as soon as possible after enucleation (up to a maximum of 5 hours), and the cut surface of the tumour was pressed against multispot slides to give a monolayer of tumour cell imprints. The slides were snap frozen and stored in liquid nitrogen for further use. Cell impressions from 8 different choroidal melanomas were used in this study to test for the presence of actin in tumour cells.

\section{Results}

The purity of the actin protein preparation was assessed by sodium dodecyl sulphate polyacrylamide gel electrophoresis (Fig. 1).

The presence of antiactin antibody in the rabbit sera was confirmed by the immunofluorescent staining patterns obtained when the sera were tested against the smooth muscle cells of the blood vessel wall, the muscularis mucosae and smooth muscle fibres between the glands of the stomach, 


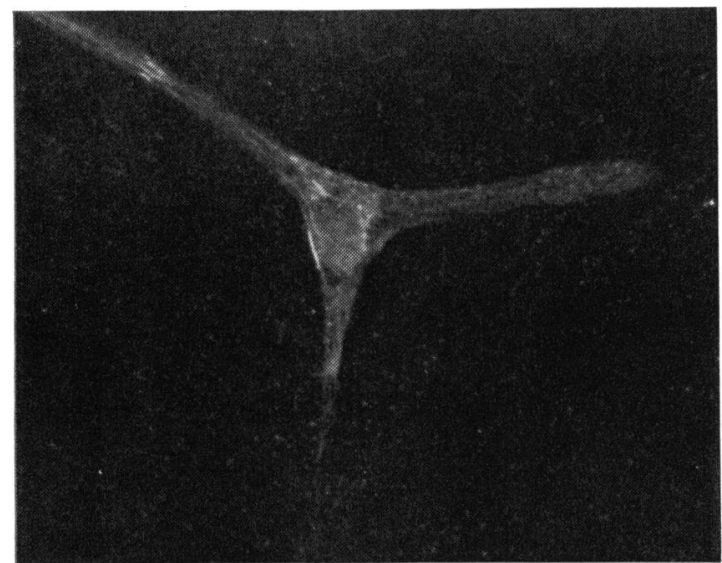

Fig. 3 Indirect immunofluorescence staining of a single malignant melanoma cell in culture preparation treated with antiactin antibodies. The pattern of staining suggests that the filamentous form of actin is present in the cytoplasm $(\times 567)$.

the myoepithelial cells of the parotid gland, liver cells in the region of the cell membranes (polygonal staining pattern), and the actin-containing I bands of skeletal muscle. ${ }^{38} 39$ In each case the staining pattern corresponded to that reported by Trenchev et $a .^{3}$ using antiactin antibodies.

The antiactin sera gave strong cytoplasmic fluorescence with all 8 choroidal malignant melanoma cell impressions. As well as diffuse fluorescence of the cytoplasm, filamentous fluorescence was also observed in the region of the cell processes (Figs. 2 and 3).

The patterns of staining described above were diminished when the sera were absorbed against actin prior to testing, the reduction being most marked when the sera were tested in high dilutions.

\section{Discussion}

In an earlier study we reported the presence of intracytoplasmic microfilaments of 4-7 $\mathrm{nm}$ diameter in choroidal malignant melanoma cells and suggested that these filaments were probably actin. ${ }^{32}$ It was also speculated then that the 'false' positive immunofluorescence obtained by testing the sera of patients with nonmalignant eye diseases against the cells of a malignant melanoma might be due to the smooth muscle antibody demonstrated in the serum of these patients. ${ }^{40}$

In the present study by subjecting the melanoma cells to an antiserum raised against a known purified preparation of actin we have been able to demonstrate with some certainty that choroidal malignant melanoma cells contain actin protein. Moreover, since the pattern of immunofluorescence assumed filamentous and diffuse forms, it is reasonable to suppose that the actin was present in either a filamentous or a depolymerised globular state.

The present study reinforces our claim that the results of immunological tests for the diagnosis of choroidal melanoma based on reactions between patient's serum and preparations of uveal melanoma cells need to be interpreted with circumspection. This is not to say that antibodies to tumour-specific antigens are not a feature of patients with uveal malignancy but rather to emphasise that before such a claim can be made it is essential to exclude the presence of antibodies to actin and, possibly, other cell components.

The significance of the contractile protein filaments in the tumour cells is unknown, though it is reasonable to speculate that they are related to the motility of the cells and hence to the capacity for infiltration and invasion characteristic of malignant tumours.

\section{References}

${ }^{1}$ Pollard TD, Weihing RR. Actin and myosin and cell movement. Crit Rev Biochem 1974; 2: 1-65.

${ }^{2}$ Lazarides E, Weber $K$. Actin antibody: The specific visualization of actin filaments in non-muscle cells. Proc Natl Acad Sci USA 1974; 71 : 2268-72.

${ }^{3}$ Trenchev $\mathbf{P}$, Sneyd P, Holborow EJ. Immunofluorescent tracing of smooth muscle contractile protein antigens in tissues other than smooth muscle. Clin Exp Immunol 1974; 16: 125-36.

${ }^{4}$ Holborow EJ, Trenchev PS, Dorling J, Webb J. Demonstration of smooth muscle contractile protein antigens in liver and epithelial cells. Ann NY Acad Sci 1975; 254: 489-504.

${ }^{5}$ Fagraeus A, Norberg R. Anti-Actin Antibodies. Curr Top Microbiol Immunol 1978; 82: 1-13.

${ }^{6}$ Lazarides E. Immunofluorescence studies on the structure of actin filament in tissues. J Histochem Cytochem 1975; 23: 505-18.

${ }^{7}$ Feeny A, Mixon RN. An in-vitro model of phagocytosis in bovine and human retinal pigment epithelium. Exp Eye Res 1976; 22: 533-48.

${ }^{8}$ Becker EL. Stimulated neutrophil locomotion. Arch Pathol Lab Med 1977; 101 : 509-13.

${ }^{9}$ Gabbiani G, Trenchev P, Holborow EJ. Increase of contractile proteins in human cancer cells. Lancet 1975; 2: 796-7.

${ }^{10}$ Pollack R, Osborn M, Weber H. Patterns of organisation of actin and myosin in normal and transformed culture cells. Proc Natl Acad Sci USA 1975; 72: 994-8.

${ }^{11}$ Lampert IA, Trenchev P, Holborow EJ. Contractile protein changes in the regenerating rat liver. Virchows Archiv Cell Pathol 1974; 15: 351-5.

${ }^{12}$ Johnson GD, Holborow EJ, Glynn LE. Antibody to smooth muscle in patients with liver diseases. Lancet 1965; 2: 878-9.

${ }^{13}$ Willingham S, Mackay JR, Irwin J. Autoimmune hepatitis. Immunofluorescence reactions with cytoplasm of smooth muscle and renal glomerular cells. Lancet $1966 ; 2$ : 1333-5.

${ }^{14}$ Johnson GD, Holborow EJ, Glynn LE. Antibody to liver in lupoid hepatitis. Lancet 1966; 2 : 416-8. 
${ }^{15}$ Farrow LJ, Holborow EJ, Brighton WD. Reaction of human smooth muscle antibody with liver cells. Nature 1971; 232: 186-7.

${ }^{16}$ Biberfeld G, Fagraeus A, Lenkei R. Reaction of smooth muscle antibody with thyroid cells. Clin Exp Immunol 1974; 18: 371-9.

${ }^{17}$ Sutton RNP, Emond RTD, Thomas PB, Doniach D. The occurrence of autoantibodies in infectious mononucleosis. Clin Exp Immunol 1974; 17: 427-36.

${ }^{18}$ Gabbiani G, Ryan GB, Lamelin JP, et al. Human smooth muscle autoantibody: its identification as antiactin antibody and a study of its binding to 'nonmuscular' cells. $A m J$ Pathol 1973; 72: 473-84.

${ }^{19}$ Fagraeus A, The H, Biberfeld G. Reaction of human smooth muscle antibody with thymus medullary cells. Nature 1973; 246: 113-5.

${ }^{20}$ Gabbiani G, Ryan GB, Badonnel MC, Majno G. Smooth muscle antigens in platelets. Immunofluorescent detection using human anti-smooth muscle serum. Pathol Biol (Paris) 1972; 20: 6-8.

${ }^{21}$ Norberg R, Lidman K, Fagraeus A. Reaction of human smooth muscle antibody with human platelets. Clin Exp Immunol 1975; 21 : 284-8.

${ }^{22}$ Andersen P, Andersen HK. Smooth muscle antibodies and other tissue antibodies in cytomegalovirus infection. Clin Immunol 1975; 22: 22-9.

${ }^{23}$ Biberfeld G, Sterner G. Smooth muscle antibodies in Mycoplasma pneumonial infection. Clin Exp Immunol 1976; 24: 287-91.

${ }^{24}$ Holborow EJ, Hemsted EH, Mead SV. Smooth muscle autoantibodies in infectious mononucleosis. $\mathrm{Br}$ Med $\mathrm{J}$ $1973 ; 3: 323-5$.

${ }^{25}$ Lidman K, Biberfeld G, Fagraeus A, et al. Anti-actin specificity of human smooth muscle antibodies in chronic active hepatitis. Clin Exp Immunol 1976; 24: 266-72.

${ }^{26}$ Farrow LJ, Holborow EJ, Johnson GD, et al. Autoantibodies and the hepatitis-associated antigen in acute infective hepatitis. $\mathrm{Br}$ Med J 1970; 2: 693-5.

${ }^{27}$ Rahi AHS, Holborow EJ, Perkins ES, Gungen YY, Dinning WJ. Immunological investigation in uveitis. Trans Ophthalmol Soc UK 1976; 96: 113-22.

${ }^{28}$ Lamelin JP, Williams EH, Souissi T, De-Thé G, Gabbiani G. Smooth muscle antibody in Burkitt's lymphoma and in nasopharyngeal carcinoma. Clin Exp Immunol 1977; 28: 157-62.

${ }^{29}$ Lamelin JP, De-Thé G, Revillard JP, Gabbiani G. Antoantibodies (Cold lymphocytotoxins, antiactin antibodies and antinuclear factors) in nasopharyngeal carcinoma patients. IARC Sci Publ 1978; 20: 523-36.

${ }^{30}$ Wasserman J, Glas U, Blombren $\mathbf{H}$. Antibodies in patients with carcinoma of the breast. Clin Exp Immunol 1975; 19: 417-22.

${ }^{31}$ Whitehouse JNA, Holborow EJ. Smooth muscle antibodies in malignant disease. $\mathrm{Br}$ Med $J$ 1971; 4: 511-3.

${ }^{32}$ Rahi AHS, Garner A, Malaty AHA. Contractile protein antigens in the cells of malignant melanoma of the choroid and their diagnostic significance. Br J Ophthalmol 1978; 62: $394-401$.

${ }^{33}$ Iyengar MR, Weber, HH. The relative affinities of nucleotides to G-actin and their effects. Biochem Biophys Acta 1964; 86: 543-53.

${ }^{34}$ Spudich JA, Watt S. The regulation of rabbit skeletal muscle contraction. I. Biochemical studies of the interaction of the tropomyosin-troponin complex with actin and the proteolytic fragments of myosin. J Biol Chem 1971; 216: 1866-71.

${ }^{35}$ Lowrey OH, Rosebrough NJ, Farr AL, Randall RJ. Protein measurement with the Folin Phenol Reagent. J Biol Chem 1951; 193: 265-75.

${ }^{36}$ Laemmli UK. Cleavage of structural proteins during the assembly of the head of bacteriophage T4. Nature 1970; 227: 680-5.

${ }^{37}$ Weber K, Osborn M. The reliability of molecular weight determinations by dodecyl sulphate-polyacrylamide gel electrophoresis. J Biol Chem 1964; 244: 4406.

${ }^{38}$ Andersen P, Small JV, Sobieszek A. Studies on the specificity of smooth muscle antibodies. Clin Exp Immunol 1976; 26: 57-66.

${ }^{39}$ Chaponnier C, Kohler L, Gabbiani G. Fixation of human anti-actin autoantibodies on skeletal muscle fibres. Clin Exp Immunol 1977; 27: 278-84.

${ }^{40}$ Malaty AHA, Rahi AHS, Garner A. Ostensible antimelanoma antibodies in patients with non-malignant eye disease. In: Silverstein AM, O'Connor GR, eds. Immunology and Immunopathology of the Eye. New York: Masson, 1979: 216-21. 